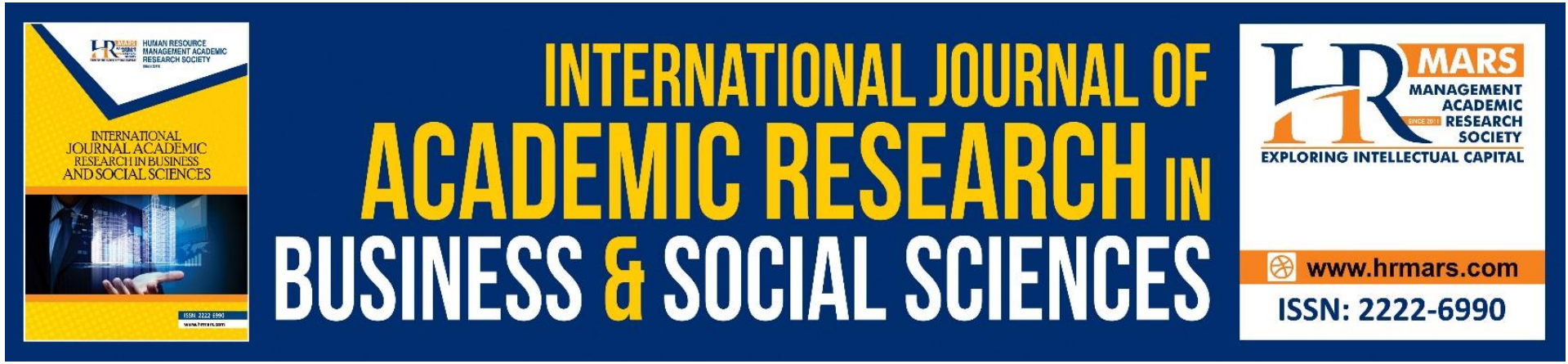

\title{
Covid-19 Influence on the Content of Aptagro, Enfagrow and Friso Gold Milk Formula Facebook Description Advertisements
}

Nur Widad Roslan, Suraya Amirrudin, Siti Nur Aliaa Roslan, Nur Maisarah Roslan

To Link this Article: http://dx.doi.org/10.6007/IJARBSS/v11-i8/10136 DOI:10.6007/IJARBSS/v11-i8/10136

Received: 08 June 2021, Revised: 30 June 2021, Accepted: 20 July 2021

Published Online: 10 August 2021

In-Text Citation: (Roslan et al., 2021)

To Cite this Article: Roslan, N. W., Amirrudin, S., Roslan, S. N. A., \& Roslan, N. M. (2021). Covid-19 Influence on the Content of Aptagro, Enfagrow and Friso Gold Milk Formula Facebook Description Advertisements. International Journal of Academic Research in Business and Social Sciences, 11(8), 520-533.

Copyright: @ 2021 The Author(s)

Published by Human Resource Management Academic Research Society (www.hrmars.com) This article is published under the Creative Commons Attribution (CC BY 4.0) license. Anyone may reproduce, distribute, translate and create derivative works of this article (for both commercial and non-commercial purposes), subject to full attribution to the original publication and authors. The full terms of this license may be seen at: http://creativecommons.org/licences/by/4.0/legalcode

Vol. 11, No. 8, 2021, Pg. 520 - 533

Full Terms \& Conditions of access and use can be found at http://hrmars.com/index.php/pages/detail/publication-ethics 


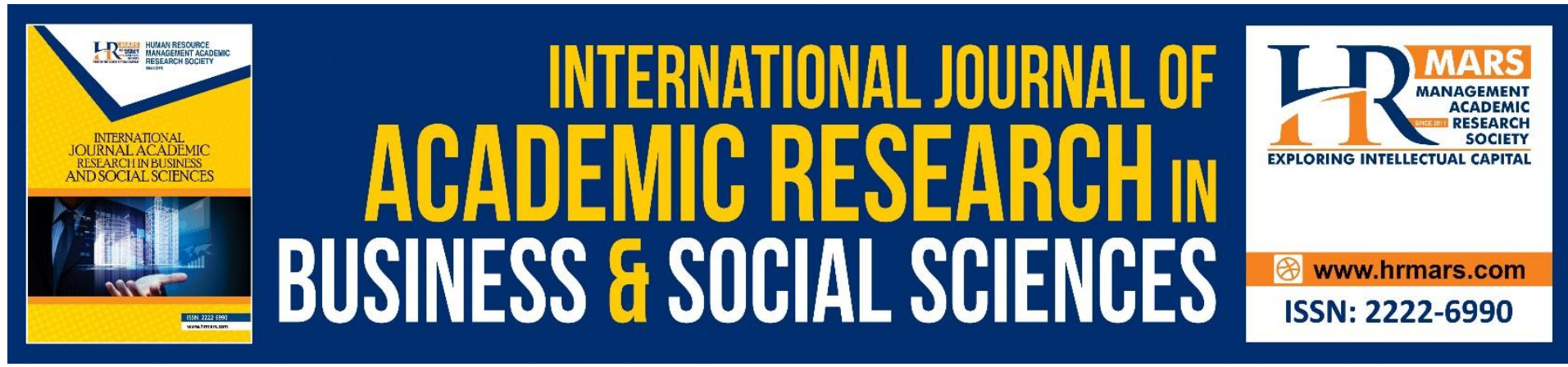

\title{
Covid-19 Influence on the Content of Aptagro, Enfagrow and Friso Gold Milk Formula Facebook Description Advertisements
}

\author{
${ }^{1}$ Nur Widad Roslan, ${ }^{1}$ Suraya Amirrudin ${ }^{2}$ Siti Nur Aliaa Roslan, \\ ${ }^{3}$ Nur Maisarah Roslan \\ ${ }^{1}$ Faculty of Business, Information and Human Sciences, Infrastructure University Kuala \\ Lumpur (IUKL), Kajang, 43000, Selangor, Malaysia, ${ }^{2}$ Faculty of Engineering, Science \& \\ Technology, Infrastructure University Kuala Lumpur (IUKL), Kajang, 43000, Selangor, \\ Malaysia, ${ }^{3}$ Centre for Preparatory Studies and Languages Al-Madinah International \\ University, 57100 Kuala Lumpur, Malaysia \\ Email: widad.roslan@gmail.com
}

\begin{abstract}
The COVID-19 pandemic has become the main social practice that influences all contents in the advertising. It has become a crucial time for brands to monitor what they advertise as it can be beneficial or sensitive. Most brands in the industry are creating content surrounding the COVID-19 outbreak. The milk formula industry is one of the industries that has connected their content from the influence of the social practice of the COVID-19 pandemic. Milk formula brands have opted to use their social media to advertise their product through fear based emotional appear towards parents. In the advertisement, they emphasised the milk formula brands offer the best for their children so that parents will not need to worry from the COVID-19 on their children. This research is a qualitative research focusing on social practice analysis from Fairclough (1995) critical discourse analysis. 3 super premium milk formula brands Facebook description content advertisement were analysed. 3 Facebook descriptions were analysed for every brand, one from 2019 before the COVID-19 outbreak, one from 2020 at the beginning of the COVID-19 outbreak in Malaysia and one in 2021, one year with the COVID-19 pandemic. The findings showed that the content from the milk formula brands for the pre COVID-19 outbreak was very generic and the product based on the Facebook descriptions in 2020 and 2021 included the COVID-19 content explicitly and implicitly. This showed that the social practice of the COVID-19 pandemic had influenced the content of the milk formula in a big way via its Facebook description post and how the industry is adapting to the pandemic situation and assuring parents that their brands are the best to protect their children. It is hoped that the future research could be done on the milk formula advertisements and the effectiveness of the digital advertising in comparison to the traditional advertising for the milk formula industry.
\end{abstract}

Keywords: Social Practice Analysis, Critical Discourse Analysis, Social Media Advertising, Milk Formula, Covid-19 


\section{Introduction}

Advertising is one of the biggest industries that is used by most brands to advertise their product or services. It does not come to a surprise that most brands are using social media as their main platform to advertise their product or services. Social media are platforms used by any users to build their network and socialising with other users virtually by using words, pictures and/or videos. In 2020 alone, Facebook had 2.7 billion active users (Statista, 2021) whilst Instagram has 1 billion active users (Statista, 2021). This shows the amount of time users spend on their smart phone and scrolling through their social media. Through this, brands have opted to advertise their product or services through social media, in order to have a bigger and closer impact to their target audience (Appel et al., 2020). This is because, social media is used for users to socialise, and when brands advertise through social media, it brings the brand and users closer together. The covid-19 pandemic has had a significant impact onto all industries especially brands; as brands need to sustain their business. With this, the social practice of the pandemic situation influences the brand's content. As covid-19 gets more serious, parents are more worried about the safety of their children. Therefore, the milk formula industry plays a big factor in assuring parents of their children's health through their advertisement of their products (Hastings et al., 2020). With this, it can be seen that many milk formula brands have shifted their messaging according to the social practice influence of the COVID-19 pandemic.

\section{Literature Review}

Digital advertising has been the main platform for brands to advertise their product or service as users spend most of their time on social media. Klieijan et al (2020) mentioned that digital advertising or marketing is catered for brands to enhance their main goal of influencing the consumers purchasing decision and for consumers to buy or be influenced by the advertisement. Unlike traditional advertising, Klieijan et al (2020) elaborated that digital is an effective platform to reach consumers as it is the most used platforms by the users and it is easy for the users to access the information by their favourite brands or be advertised by brands that they have never heard of. A study by Alrwashdeh et al (2019) had examined the effectiveness of word-of-mouth through the digital platform to enhance the customers purchasing intentions and increase the consumers' knowledge on brad image. A total of 402 smartphone users from North Cyprus participated in the study through online questionnaires and the findings showed that the effects from digital word of mouth had managed to influence the consumers purchasing decision and the word of mouth given through the digital platforms also gave a moderate impact towards consumers about the brand name and image. The study showed how word of mouth does not only need to be present in physical form, but also happen on digital platform. On the other hand, the study by Alrwashdeh et al (2019) indicated that word of mouth through digital platform is more efficient and reaches consumers faster as the information is only at the tip of their fingers as they scroll through their digital platforms. Similarly, Prasad \& Garg (2019) supports Alrwashdeh et al., (2019) on word of mouth and further elaborated that digital word of mouth can either be able to influence or not influence their target audience depending on the objective of the advertisement. Prasad \& Garg (2019) study had focused on the digital word of mouth towards generation $Y$ consisting of university students and the results of the study had showed that digital word of mouth advertisement was mainly developed to increase customer loyalty, consumers purchasing decision and brand reputation. However, Meslat (2018) study had a difference in opinion on the influence of digital advertising towards consumers purchasing 
decision. But instead of word of mouth like Alrwashdeh et al., (2019) study, Meslat (2018) had researched on the ineffectiveness of Facebook advertising on a chocolate manufacturing company by "Chocolaterie Thibaut". The research had used mixed methods of doing interviews and questionnaires for data collection and the findings showed that the consumers for the brand was primarily woman of aged above 60 and are not well aware of the digital platform. From the Meslat (2018) research, it was found that the platform used to advertise the brand is not suitable for their consumers hence why advertising on the brand's Facebook page was not affective as it did not reach to their target audience. Hence, it is very important for brands to identify and research their target audience to be able to choose the correct platform to advertise their product and services.

With the increase of digital advertising, infant milk formula industry has fully adapted to the digital world by using digital as their main platform to advertise their product. Hastings et al., (2020) study had highlighted their concerns in regards to infant formula advertising as infant formula brands are using advertising agency to develop content to advertise their product and sometimes the advertisements does not comply to the code of conducts set by the milk formula ethics committee. The mixture of creativity to make milk formula more sophisticated and simple-minded is causing harm towards public health. With this, Hasting et al., (2020) study had found that the emotional techniques used in milk formula advertisements had caused inferior towards the most important element which is breast milk, therefore the study suggested that regulations on the International Code of Marketing of Breast milk Substitute needs to be further tightened in order to guide advertising agencies and the milk formula brands in developing advertisements that is in line with the regulations provided for the safety and health of the public. Li et al., (2021) supports Hastings et al., (2020) and further added that advertising milk formula towards consumers' needs to be well considered and the background research on the consumers' needs to be fully understood in order to choose the right advertising medium to promo the milk formula brand. The study showed that different types of advertising techniques are used to promote milk formula in China as the study elaborated that those in rural areas are most influenced by free samples that they receive whilst those living in the cities depends on social media as the modern mass media to receive information about milk formula. With this, Li et al (2021) study found that the type of advertising used by brands differs according to their target audience lifestyle as it plays a big role in understanding the target audience's behaviour. Other than that, Ching et al (2021) agrees with Hastings et al (2020); Li et al (2021), as Ching et al (2021) had found that many milk formula brands are violating the International Code of Marketing of Breast Milk Substitutes by undermining the child health because of the COVID-19 Pandemic. Inappropriate advertising of breast milk substitutes which is formula milk can threaten the breastfeeding environment as well as child mortality, morbidity and malnutrition, hence why advertising formula milk is a very important and sensitive issue. Ching et al (2021) study had observed and reviewed promotional materials of 9 milk formula companies in 14 countries which they were able to identify different advertising strategies used to advertise the milk formula. From the strategies observed, it was found by Ching et al (2021) that the advertisements were riding on fear related to the COVID-19 Pandemic by highlighting health claims about the milk formula that will help children in fighting COVID-19. Although pass studies showed that instilling fear in advertisements are not new, but as the COVID-19 appears, it has caused an increase of using fear as brands main strategy and fully utilising the digital platform to create that fear awareness. Other than that, additional promotional tactics 
are used as donations and services in order to create hope and solidarity amongst their target audience. The findings showed that in 2020 the start of the COVID-19 outbreak, Philippines had increased its violations towards the regulations of advertising for Milk Formula from 70 violations in 2019 to 291 during the first month of the COVID-19 outbreak. This showed that brands took the risk to not follow the regulation provided by the International Code of Marketing of Breast Milk Substitutes and advertise to cater to the current trend which was the COVID-19 pandemic that parents feared for the children. The findings showed that the public had a lack of awareness in regards to donations for milk formula and not having extensive knowledge about the regulations set when it comes to advertising for milk formula. With this, Ching et al (2021) had proposed more detailed monitoring is done on milk formula brands and to increase the public's knowledge on breastfeeding through the context of COVID-19. Additionally, the use of social media to educate public, brands and advertisers are proposed so that the correct information is given. Through Ching et al (2021) study, it showed that the content of milk formula advertisement is very important so that it does not go against the regulations set. On the other hand, the studies on milk formula also showed how the social practice influences the content of the advertisement, and for Ching et al (2021) study, the social practice of the COVID-19 Pandemic had influenced the content of the advertisement, but did not follow the regulations. With this, it is important for brands and advertising agencies to know and understand the social practice analysis in Milk formula television advertisement and how it influences the content and messaging of the advertisement.

Objective of this study is to identify and discuss Fairclough's (1995) critical discourse analysis third dimension which is social practice analysis in super premium milk formula brand Facebook product advertisement.

\section{Methodology}

This study used qualitative method of critical discourse analysis, focusing on the social practice analysis of the COVID-19 pandemic and its influence towards milk formula Facebook description advertisement. 9 advertisements were analysed from 3 super premium brands in Malaysia which was AptaGro, Enfagrow A+ Mindpro and Friso Gold. Super premium brands are the most expensive milk formula brands available in Malaysia. Super premium brands were chosen for this study as all the 3 brands were based on the only made available in Malaysia circa 2018/2019 and were the competitors among each other. The price range for the milk formula is as below:

\section{Price Range (Shopee)}

\begin{tabular}{|l|l|l|l|}
\hline & AptaGro & Enfagrow A+ Mindpro & Friso Gold \\
\hline Step 3 (1-3 yrs) & RM99.90/1.2kg & RM103.70/1.2kg & RM101.00/1.2kg \\
\hline Step 4 (4+ yrs) & RM88.90/1.2kg & RM90.68/1.2kg & RM89.00/1.2kg \\
\hline
\end{tabular}

The study had analysed three different Facebook description posts from each brand (9 Facebook description posts in total). One Facebook description post from 2019 to analyse the content of the advertisement before the COVID-19 breakout, one in 2020 to analyse the content as the COVID-19 started in Malaysia and one Facebook description post in 2021, to analyse the content 1 year post COVID-19 breakout. The Facebook description posts was analysed with Fairclough's (1995) social practice analysis that highlighted the influence of social practice towards text, and for this research was the COVID-19 Pandemic's influence 
towards the content and message of Milk Formula Facebook advertisement. Only the Facebook description post was analysed, which was the description at the top of the post, boxed in red as below:

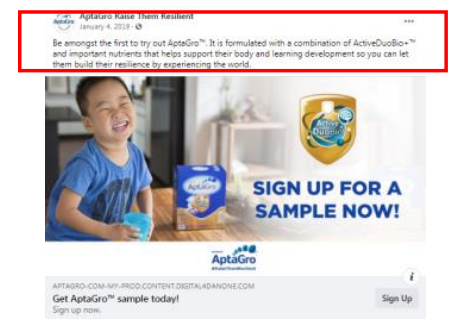

Chosen Advertisement on the brand's official Facebook Page

\begin{tabular}{|c|c|c|c|}
\hline & 2019 (Pre Covid-19) & 2020 (Start of Covid-19) & 2021 (1 year post covid-19) \\
\hline AptaGro & $\begin{array}{l}\text { Be amongst the first to } \\
\text { try out AptaGro }{ }^{\mathrm{TM}} \text {. It is } \\
\text { formulated with a } \\
\text { combination of } \\
\text { ActiveDuoBio+ }^{\mathrm{TM}} \text { and } \\
\text { important nutrients that } \\
\text { helps support their body } \\
\text { and learning } \\
\text { development so you can } \\
\text { let them build their } \\
\text { resilience by } \\
\text { experiencing the world. }\end{array}$ & $\begin{array}{l}\text { Do not let your loved ones } \\
\text { be part of the influenza } \\
\text { statistics. Protect them by } \\
\text { boosting the army of good } \\
\text { bacteria. AptaGro }{ }^{\mathrm{TM}} \text { is } \\
\text { formulated with } \\
\text { internationally patented } \\
\text { combination of Prebiotics } \\
\text { and Probiotic to boost the } \\
\text { army of good bacteria and } \\
\text { help support your child's } \\
\text { body. \#AptaGro } \\
\text { \#RaiseThemResilient }\end{array}$ & $\begin{array}{l}\text { Have you been feeding } \\
\text { your child with all the right } \\
\text { foods they need especially } \\
\text { during these challenging } \\
\text { times? Learn how you can } \\
\text { strengthen your child's } \\
\text { immunity through a rich } \\
\text { intake of Prebiotics \& } \\
\text { Probiotic, and other } \\
\text { vitamins to better combat } \\
\text { harmful germs! } \\
\text { \#AptaGro } \\
\text { \#StrongSmartStart } \\
\text { \#RaiseThemResilient }\end{array}$ \\
\hline $\begin{array}{l}\text { Enfagro } \\
\text { w At } \\
\text { Mindpr } \\
\text { o }\end{array}$ & $\begin{array}{l}\text { A year older means } \\
\text { another year to learn } \\
\text { and explore the world } \\
\text { around her. You have } \\
\text { given her the world, and } \\
\text { you can continue to do } \\
\text { so by giving her good } \\
\text { nutrition to support her } \\
\text { growth. } \\
\text {-Compared to previous } \\
\text { formulation. Enfagrow } \\
\text { A+ provides } 105 \mathrm{mg} \text { DHA } \\
\text { in } 3 \text { servings per day }\end{array}$ & $\begin{array}{l}\text { Scientific studies have } \\
\text { shown that MFGM and DHA } \\
\text { help support mental }{ }^{3} \text { and } \\
\text { emotional^ development. } \\
{ }^{3} \text { Kuratko, C.N. et al. } 2013 . \\
\text { The relationship of } \\
\text { Docosahexaenoic Acid (DHA) } \\
\text { with learning and behavior } \\
\text { in healthy children: A review. } \\
\text { Nutrients, 5(7), } 2777 \text { 2810. } \\
\text { http://doi.org/10.3390/nu50 } \\
72777 \\
\text { ^Veeraman Wauters G, et. } \\
\text { Al. Nutrition (2012); } 28: 749 \\
752 \text {. } \\
\text { *Compared to key growing } \\
\text { up milk brands in the market } \\
\text { as of Sept } 2019 . \text { Enfagrow } \\
\text { A+ provides } 105 \text { mg DHA in } 3 \\
\text { servings per day. }\end{array}$ & $\begin{array}{l}\text { Your child's learning never } \\
\text { stops. With a strong } \\
\text { immunity, it's possible. } \\
\text { Help support their } \\
\text { immunity and brain } \\
\text { development with } \\
\text { scientifically backed } \\
\text { ingredients - MFGM \& } \\
\text { DHA. Research shows that } \\
\text { MFGM supports } 35 \% \text { fewer } \\
\text { sick days* and when } \\
\text { coupled with DHA, gives } 2 x \\
\text { benefits for brain cell } \\
\text { connections1-2. } \\
\text { Introducing the new } \\
\text { Enfagrow A+ MindPro, the } \\
\text { only brand with MFGM \& } \\
\text { Highest DHA^, now with no } \\
\text { sugar added }+ \text {. }\end{array}$ \\
\hline
\end{tabular}




\begin{tabular}{|c|c|c|c|}
\hline & & & $\begin{array}{l}\text { *Veereman-Wauters G, et } \\
\text { al. Nutrition. 2012; 28:749- } \\
752 . \\
{ }^{1} \text { Hussain. G et al. Lipids } \\
\text { Health Dis 18, } 26 \text { (2019) } \\
{ }^{2} \text { Kuratko, CN. Et al.2013. } \\
\text { Nutrients, 5(7), 277-2810 } \\
\text { ^Compared to key growing } \\
\text { up milk brands in the } \\
\text { market as of August } 2020 . \\
\text { Enfagrow A+ MindPro } \\
\text { provides } 120 \text { mg DHA in } 3 \\
\text { servings per day. } \\
\text { Applicable to S3 and S4 } \\
\text { only. } \\
\text { †Sugar refers to sucrose } \\
\text { based on Regulation } 118 \\
\text { under Malaysia Food } \\
\text { Regulation } 1985\end{array}$ \\
\hline $\begin{array}{l}\text { Friso } \\
\text { Gold }\end{array}$ & $\begin{array}{l}\text { Make a perfect glass, } \\
\text { every time. Designed } \\
\text { with an accurate scoop } \\
\text { guide, hygienic spoon } \\
\text { rest, and tight seal for } \\
\text { freshness. }\end{array}$ & $\begin{array}{l}\text { Rest assured, our nutritious } \\
\text { milk is } 100 \% \text { made in The } \\
\text { Netherlands from grass to } \\
\text { glass - tested and approved } \\
\text { by mums!* Get the best of } \\
\text { nature, made better by } \\
\text { science to care for your } \\
\text { child's tummy with quality } \\
\text { natural nutrition, for easy } \\
\text { digestion and absorption. } \\
\text { Friso Gold } \\
\text { side to stays by your } \\
\text { overall growth and immune } \\
\text { system, with over } 50 \\
\text { essential nutrients, including } \\
\text { prebiotics and probiotics to } \\
\text { build a \#Strongerlnside. Give } \\
\text { it a try and 'Add to Cart' } \\
\text { from our official stores } \\
\text { today! } \\
\text { Lazada: } \\
\text { www.lazada.com.my/shop/f } \\
\text { riso-gold-official-store } \\
\text { Shopee: } \\
\text { www.shopee.com.my/friso.o } \\
\text { s }\end{array}$ & $\begin{array}{l}\text { Introducing the NEW } \\
\text { Upgraded Friso }{ }^{\circledR} \text { Gold }{ }^{\curvearrowright} \\
\text { Fully Imported from the } \\
\text { Netherlands } \\
\text { Our NEWLY upgraded } \\
\text { Friso }^{\circledR} \text { Gold with NOVAS } \\
\text { Signature Milk contains } \\
\text { naturally small molecules } \\
\text { and soft structure so it's } \\
\text { easy to digest. Natural } \\
\text { nutrients are preserved } \\
\text { with our unique LocNutri' } \\
\text { Technology so that } \\
\text { goodness of our milks' } \\
\text { nutrients are closer to its } \\
\text { native structure. } \\
\text { Now with no added } \\
\text { Sucrose or Flavour, Friso } \\
\text { Gold is packed with the } \\
\text { goodness of over } 50 \\
\text { essential nutrients } \\
\text { including DHA \& GOS to } \\
\text { supplement your child's } \\
\text { growth, naturally. }\end{array}$ \\
\hline
\end{tabular}




\begin{tabular}{|l|l|l|}
\hline & $\begin{array}{l}\text { *Survey conducted by Home } \\
\text { Tester Club between 3/3/20 } \\
\text { and 15/4/20, 270 members } \\
\text { have received and home } \\
\text { tested Friso Gold }\end{array}$ \\
\hline
\end{tabular}

\section{Results and Discussion}

Pre COVID-19 Advertisement (2019)

It is found that for AptaGro Facebook advertisement in 2019 before COVID-19 outbreak that AptaGro was promoting their product and encouraging their target audience to try the milk formula as they had just entered the Malaysian market and by doing so by stating "Be amongst the first to try out AptaGro ${ }^{\text {TM" }}$. The description also further highlighted their product benefits throughout the Facebook post description "It is formulated with a combination of ActiveDuoBio+ ${ }^{\mathrm{TM}}$ and important nutrients that helps support their body and learning development so you can let them build their resilience by experiencing the world". This showed that the brand was advertising the product benefits to influence their potential consumers as the brand had just been made available for the Malaysian market. The post description showed the product centric and highlighting all the milk formula's benefits physically and emotionally with their strong line of "them build their resilience by experiencing the world". The social practice presented in AptaGro's 2019 post description is influenced by the brand's status it brings from being well known in Europe, the high expectation from potential consumers are what's influences the content and messaging used in the description, hence the 2019 Facebook description detailing on the product more rather than the emotional side, in order to educate potential audience's to try the brand. Enfagrow A+ milk formula brand on the other hand was already established by 2019, therefore Enfagrow At's Faceook description post was more emotional to sustain their audience, as mentioned in the post description "A year older means another year to learn and explore the world around her". However, the post description does not forget to include the product as well by implicitly implying the product as indicated "You have given her the world, and you can continue to do so by giving her good nutrition to support her growth". The second sentence starts with an emotional appeal and continues by connecting it with the product of "giving her good nutrition to support her growth" which the brand is implying towards the product as the milk formula offered by Enfagrow A+ has nutrition's can help the growth of a child. The social practice is the target audience as the brands is sustaining the target audience through emotional appeal and potential target audience as the description still relates it back to the benefits of the product, but implicitly as to not be to product centric but also maintain the emotional appeal. Friso Gold's 2019 Facebook post description on the other hand only focused on the milk formula packaging, in which was very direct. The social practice used was to educate and influence users and potential users on brand's packaging to make that perfect cup of milk for the child as mentioned in the post description explicitly "Make a perfect glass, every time. Designed with an accurate scoop guide, hygienic spoon rest, and tight seal for freshness'. With this, the milk formula brand's 2019 post description was more product base and emotional appeal to maintain and get new customers. 


\section{Start of COVID-19 Advertisement (2020)}

2020 was the start of the COVID-19 pandemic and fear grew about the disease especially for parents. From the fear, brands started to use social media platforms to implicitly advertise their brands a one of the solutions for their children to stay safe from the COVID-19. AptaGro's 2020 Facebook description post was implicitly referring to the COVID-19 disease by stating "Do not let your loved ones be part of the influenza statistics", which is referring to the COVID19 disease that had entered Malaysia and the daily positive cases was rising, and before COVID-19 got its name, it was called an "Influenza" disease, as it is a generic term based on the symptoms that positive patients had was similar to influenza patients. The Facebook post description further added "Protect them by boosting the army of good bacteria" to which is informing users and readers about the protection children need. The post then connects the information of protecting children with the benefits that the product offers which is "AptaGro" is formulated with internationally patented combination of Prebiotics and Probiotic to boost the army of good bacteria and help support your child's body". By connecting the brands product benefits with the information about protecting children, it helps users and readers to know that AptaGro is the brand that offers the protection for your child. The social practice in AptaGro's 2020 Facebook post description is the COVID-19 pandemic and the influence it has in brands to sell their product as one of the ways for children to be safe from the COVID-19. Subsequently, Enfagrow A+ also showed a difference in Facebook description post in 2020 as the description was to get users and readers to trust in the milk formula as the brand kept the description short but precise "Scientific studies have shown that MFGM and DHA help support mental ${ }^{3}$ and emotional^ development". By using "scientific studies" it gives assurance to users and readers that the milk formula had study to prove that Enfagrow A+ milk formula product benefits is what a child need for "mental and emotional development". Although the messaging is not directly referring to the COVID-19, but because of the social practice of the COVID-19 happening in Malaysia, the description helps to assure parents with the research done to prove the milk formula benefits. Besides that, Friso Gold's 2020 Facebook post description was similar eith Enfagrow A+ as Friso Gold was explicitly assuring users and potential users by indicating "rest assured". It was to give parents the assurance that the milk formula by Friso Gold is " $100 \%$ made in The Netherlands from grass to glass - tested and approved by mums!", even by adding the "tested and approved by mums!" to further influence the readers on the milk formula offered by Friso Gold. Additionally, the post also mentioned that "get the best of nature, made better by science to care for your child's tummy with quality natural nutrition, for easy digestion and absorption". Not only does the description start with an emotional appeal to the parent, but to further strengthen the description, Friso Gold's product benefits are introduced. Additionally, at the end of the description, the post stated that "Friso Gold stays by your side to support your child's overall growth and immune system". The protection and growth of the immune system is the important element that keeps children protected from any disease, in which the social practice is the COVID-19, hence the milk formula is implicitly referring to. 2020 Facebook description advertisements showed that the COVID-19 pandemic was the social practice that had influenced the content being explicitly or implicitly implying towards the pandemic.

\section{Year Post COVID-19 Outbreak Advertisement (2021)}

A year had gone by and the COVID-19 pandemic is still around. It has become challenging for brands to create content with the seriousness of the pandemic. Hence, the milk formula 
brands of AptaGro, EnfaGrow A+ which is now Enfragrow A+ Mindpro and Friso Gold had all decided to change their image, packaging and formula for the evolving world. In AptaGro's 2021 Facebook post description, the description "Have you been feeding your child with all the right foods they need especially during these challenging times?" by questioning the readers and at the same time acknowledging that it is a "challenging time" for everyone and the brand understand the situation. Then the description continues with a solution to the question "Learn how you can strengthen your child's immunity through a rich intake of Prebiotics \& Probiotic, and other vitamins to better combat harmful germs!" in which is all offered in the brand's formula milk. The description did not state that AptaGro was the brand to offer the formula, but implicitly, it implied the brands as it is all the ingredients the milk formula has. This shows that, although it has been a year post the COVID-19 outbreak, AptaGro is still educating readers about their milk formula and assuring readers that AptaGro is the brand to strengthen a child's immunity which a child needs to protect them from diseases like COVID-19. Meanwhile for Enfagrow A+ mindpro's 2021 Facebook description had focused more on immunity. Immunity is explicitly stated in the second and third sentence "With a strong immunity, it's possible. Help support their immunity and brain development with scientifically backed ingredients - MFGM \& DHA". By including "immunity" twice in the description, it is to give importance towards the meaning of immunity as it is something that every child needs during the COVID-19 outbreak. Not only that, the description also adds supported facts from research to assure readers that it is a well-researched milk formula "Research shows that MFGM supports 35\% fewer sick days* and when coupled with DHA, gives $2 x$ benefits for brain cell connections1-2". Friso Gold on the other hand had used their "NEW Upgraded" milk formula to start their 2019 Facebook description. It's implicitly implying that the brand has upgraded to be better for the users during the COVID-19 outbreak and it is mentioned twice in the description, which shows that the information is important. The description also emphasised on the natural ingredients that the formula has "Natural nutrients are preserved with our unique LocNutri ${ }^{\mathrm{TM}}$ Technology so that goodness of our milks' nutrients are closer to its native structure", as the COVID-19 breakout is still on-going, many users are opting more natural based foods, hence Friso Gold including that information in their Facebook description. Not only that, the description also elaborates the additional product benefits it has "over 50 essential nutrients including DHA \& GOS to supplement your child's growth, naturally". By using big numbers, it helps to influence the reader's intentions towards the brands. So sum up, 2021 Facebook post description for AptaGro, Enfagrow A+ mindpro and Friso Gold's social practice is the COVID-19 pandemic and hot it had influenced the content of the Facebook description advertisement.

\section{Conclusion}

Based on the findings and discussion for this study, it shows that through Fairclough's (1995) critical discourse analysis third dimension of social practice analysis, the COVID-19 pandemic played a big role in the content and messaging of AptaGro, Enfagrow A+ mindpro and Friso Gold's Facebook description advertisements. Before the COVID-19 came to Malaysia, the content of the brands Facebook description advertisement was emotional and product centric, to maintain their current customers and attract new customers. Once COVID-19 was in Malaysia, more fear-based emotional content was used by AptaGro to get parents to try the brand. Fear base descriptions such as "Do not let your loved ones be part of the influenza statistics" and "Have you been feeding your child with all the right foods they need especially during these challenging times?" are enough to increase fear in the readers and would want 
to have a solution to that fear right away. Enfagrow A+ mindpro on the other hand focused more on educating readers that the brand has done their research and knows that the milk formula offered is the best by indicating the research in the description itself. Besides that, Friso Gold had focused on their product benefits by injecting the "natural" ingredients that they include in their milk formula. Overall, it shows that by maintaining the regulations of advertising milk formula, AptaGro, Enfagrow A+ mindpro and Friso Gold were still able to create content that is catered to the COVID-19, as it is the influence of the social issue that is happening globally. It is hoped that future research is done on milk formula advertisements and the effectiveness of digital advertising compared to traditional advertising.

\section{References}

Alrwashdeh, M., Emeagwali, O., \& Aljuhmani, H. (2019). The effect of electronic word of mouth communication on purchase intention and brand image: An applicant smartphone brands in North Cyprus. Management Science Letters. 9(4), 505-518.

Appel, G., Grewal, L., Hadi, R., \& Stephen, A, T. (2020). The future of social media in marketing. Journal of the Academy of Marketing Science. 48, 79-95.

Hastings, G., \& Angus, K., Eadie, D., \& Hunt, K. (2020). Selling second best: how infant formula marketing works. Globalization and Health. 16(10), 1186.

Kleijnen, M., Herhausen, D., Miocevic, D., \& Morgan, R. (2020). The digital marketing capabilities gap. Industrial Marketing Management. 90, 276-290.

Li, J., Nguyen, T, T., Duan, Y., Mathisen, R., \& Yang, Z. (2021). Advice to use infant formula and free samples are common in both urban and rural areas in China: a cross-sectional survey. Public Health Nutrition. 24(8), 1977 - 1988.

Meslat, N. (2018). Impact of social media on customers' purchase decision: case: Chocolaterie Thibaut, France. International Business and Administration. 1-48.

Prasad, S., Garg, A., \& Prasad, S. (2019). Purchase decision of generation $Y$ in an online environment. Marketing Intelligence \& Planning. 12(4), 24-36.

Statista. (2021). Number of Facebook users worldwide from 2015 to 2021. Retrieved on 28 May 2021: https://www.statista.com/statistics/490424/number-of-worldwidefacebook-users/

Statista. (2021). Number of Instagram users worldwide from 2016 to 2021. Retrieved on 28 May 2021: https://www.statista.com/statistics/183585/instagram-number-of-globalusers/

Teo, L. X. (2019). Marketing on Instagram: Social influence and image quality on perception of quality and purchase intention. International Journal of Sports Marketing \& Sponsorship. 20(2), 321-332. 


\section{APPENDICES}

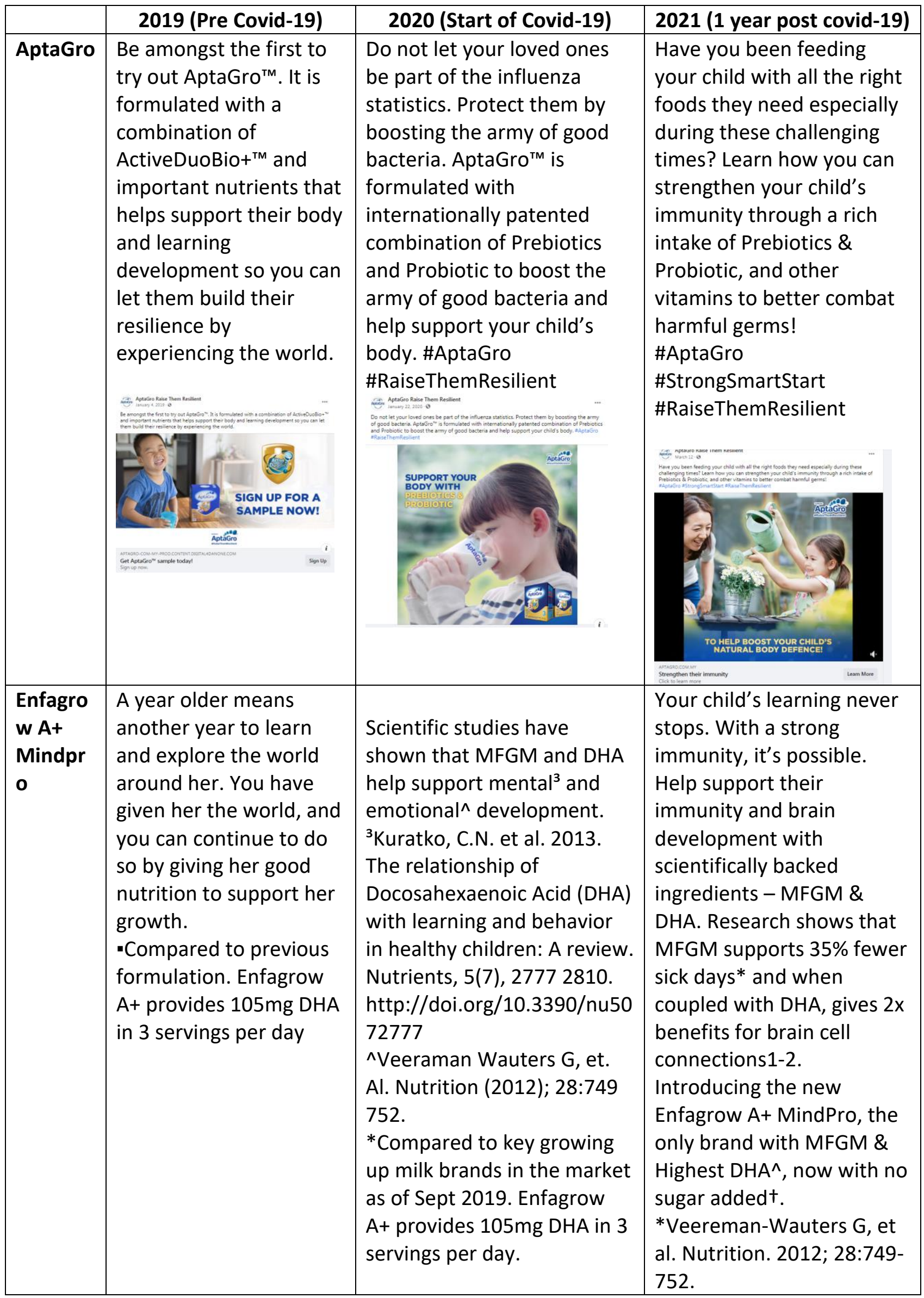




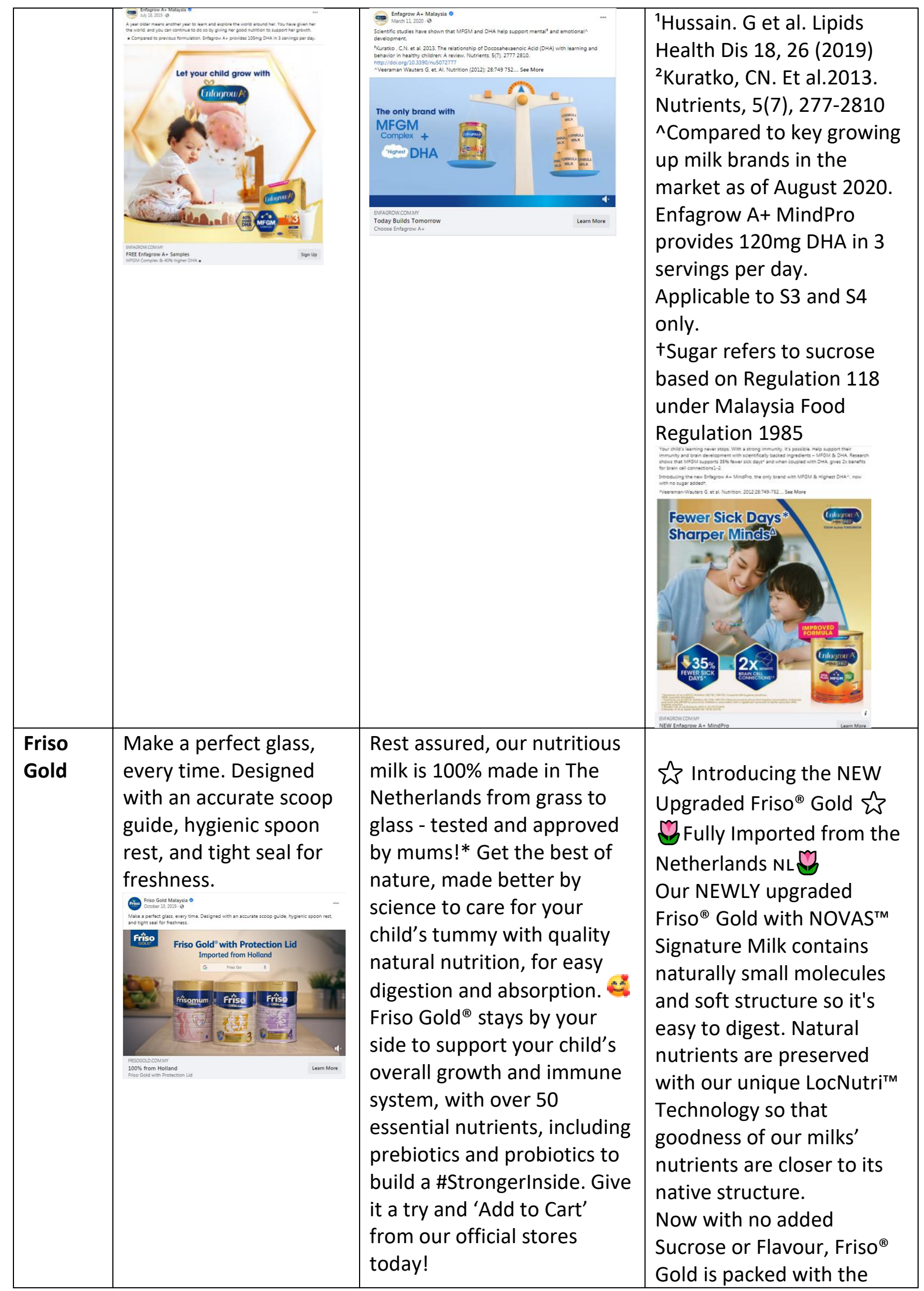




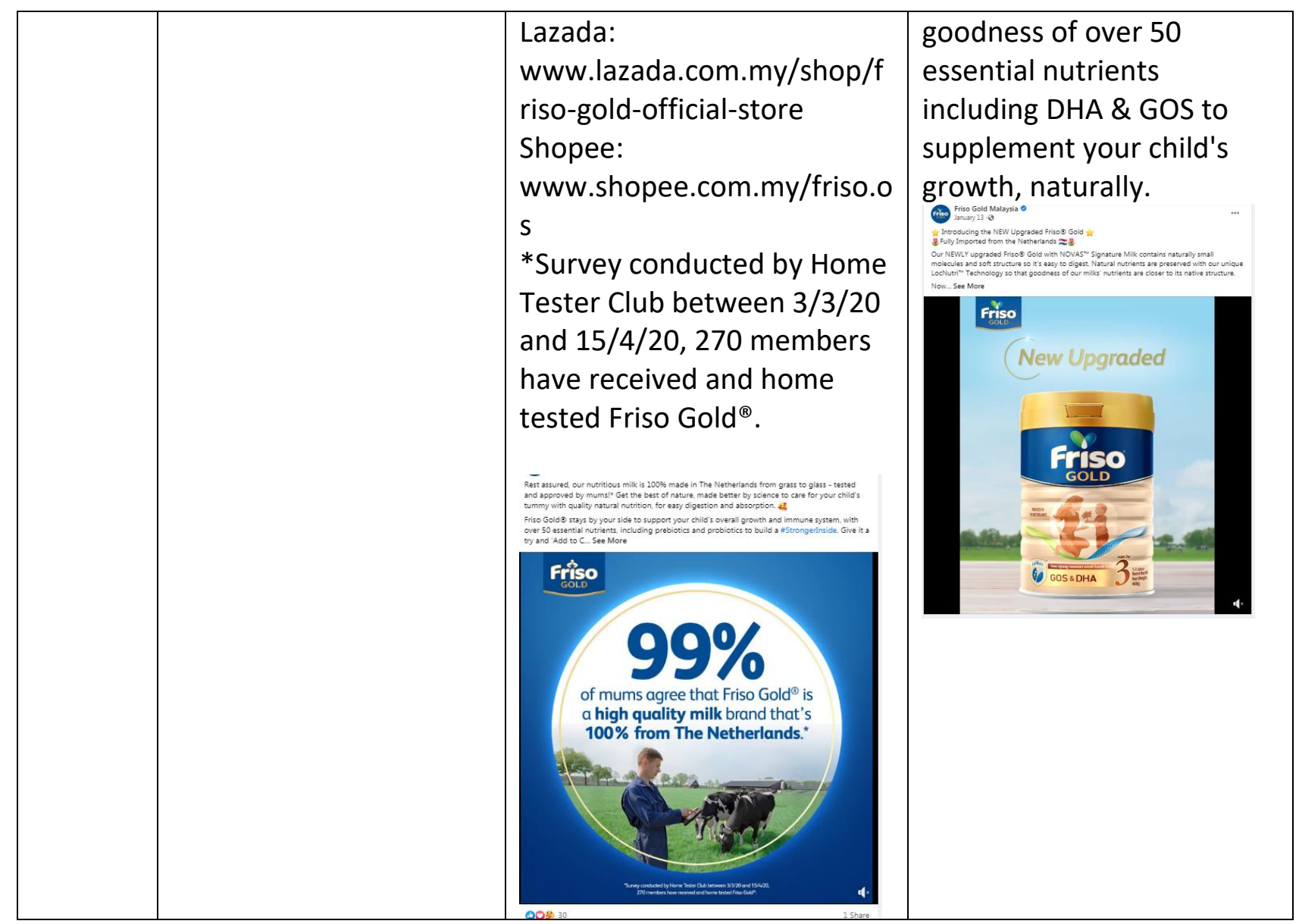

